\title{
Levels of persistent organic pollutants in eastern North Atlantic humpback whales
}

\author{
Conor Ryan ${ }^{1,2,10, *}$, Brendan McHugh ${ }^{3}$, Brian Boyle ${ }^{3}$, Evin McGovern $^{3}$, Martine Bérubé ${ }^{4}$, \\ Pedro Lopez-Suárez ${ }^{5}$, Cristiane T. Elfes ${ }^{6}$, Daryle T. Boyd ${ }^{7}$, Gina M. Ylitalo ${ }^{7}$, \\ Glenn R. Van Blaricom ${ }^{7}$, Phillip J. Clapham ${ }^{8}$, Jooke Robbins ${ }^{9}$, Per J. Palsbøll ${ }^{4}$, \\ Ian O'Connor ${ }^{1}$, Simon D. Berrow ${ }^{1,2}$
}

\author{
${ }^{1}$ Marine and Freshwater Research Centre, Department of Life Sciences, Galway-Mayo Institute of Technology, Galway, Ireland \\ ${ }^{2}$ Irish Whale and Dolphin Group, Merchant's Quay, Kilrush, Co. Clare, Ireland \\ ${ }^{3}$ Marine Institute, Rinville, Oranmore, Co. Galway, Ireland \\ ${ }^{4}$ Marine Evolution and Conservation, Centre for Ecological and Evolutionary Studies, University of Groningen, Nijenborgh 7, \\ 9747 AG Groningen, The Netherlands \\ ${ }^{5}$ Naturalia Cape Verde Lda., Sal-Rei, Boa Vista, Republic of Cape Verde \\ ${ }^{6}$ Department of Ecology, Evolution and Marine Biology, University of California Santa Barbara, Santa Barbara, California 93106, USA \\ ${ }^{7}$ Environmental Conservation Division, Northwest Fisheries Science Center, National Marine Fisheries Service, \\ NOAA, 2725 Montlake Blvd. E., Seattle, Washington 98112, USA \\ ${ }^{8}$ NOAA, Alaska Fisheries Science Center, Sand Point Way Northeast, Seattle, Washington 98112, USA \\ ${ }^{9}$ Provincetown Center for Coastal Studies, 5 Holway Avenue, Provincetown, Massachusetts 02657, USA \\ ${ }^{10}$ Present address: Marine Conservation Research, 1 High St., Colchester CO5 9AG, UK
}

\begin{abstract}
Blubber lipid concentrations of 14 organochlorine compounds and 10 polychlorinated biphenyls (PCB) were measured by gas chromatography with electron-capture detection in eastern North Atlantic humpback whales Megaptera novaeangliae from Cape Verde $(n=20)$ and Ireland $(n=4)$. Concentrations were statistically compared to those from 20 samples collected from the Gulf of Maine in the western North Atlantic. Pollutant burdens were compared using males only, in order to circumvent biases associated with reproductive offloading. Lipid-normalised PCB concentrations were below the estimated threshold toxicity value of $17000 \mathrm{ng} \mathrm{g}^{-1}$ for blubber in marine mammals. Dichlorodiphenyltrichloroethane (DDT), PCB and chlordane concentrations were an order of magnitude lower than those previously reported for Gulf of Maine humpback whales and higher than those reported from the North Pacific Ocean. Higher concentrations of lower-chlorinated PCB congeners $(28,31$ and 52$)$, hexachlorocyclohexanes and hexachlorobenzene in males in eastern North Atlantic sites is consistent with higher latitude feeding grounds. Lower $p, p^{\prime}$-DDE (dichlorodiphenyldichloroethane): $\Sigma$ DDT ratios suggest that whales from the eastern North Atlantic harbour more recent inputs of DDT. The $\Sigma$ DDTs: $\Sigma$ PCBs ratio was higher for males from Cape Verde (1.69) and Ireland (1.44), indicating proportionately greater sources of agricultural rather than industrial sources of pollutants than for the Gulf of Maine whales (0.75). We demonstrate potential for persistent organochlorine pollutants (POPs) as tracers to determine foraging ground provenance for samples collected on breeding grounds in the North Atlantic. Low concentrations suggest that POPs are unlikely to be a factor in the poor recovery rate of humpback whales in Cape Verde.
\end{abstract}

KEY WORDS: Intrinsic markers $\cdot$ Blubber $\cdot$ Biopsy $\cdot$ PCB $\cdot$ DDT $\cdot$ Migration $\cdot$ Population structure Cape Verde

Resale or republication not permitted without written consent of the publisher

\section{INTRODUCTION}

Persistent organochlorine pollutants (POPs) are almost exclusively synthetic, highly resistant to biodegradation and found in electronic components, pesticides, lubricants and flame retardants. A wide number of POPs have been banned since the 1970s in developed nations due to health concerns for both humans and wildlife. Despite regulation and bans on their usage, POPs remain widespread in the environ- 
ment through transportation by sea and air, coupled with bioaccumulation due to their lipophilic nature. Differential recalcitrance, residence and concentrations of various POPs in the environment can be investigated by long-term monitoring of long-lived, lipid-rich and top trophic level animals such as cetaceans that cannot efficiently metabolise persistent organochlorine compounds (Tanabe et al. 1988, Aguilar et al. 2002, Krahn et al. 2007).

Despite the threat that POPs may pose to the health and viability of a population, their presence can serve as an intrinsic marker from which population structure can be inferred. The delineation of 'stocks' or discrete populations is necessary to manage and conserve cetaceans effectively; however, this presents a formidable challenge (Donovan 1991). Intrinsic markers are increasingly being used to this end, including molecular genetic (Palsbøll et al. 1997), stable isotope (Ryan et al. 2013a), trace elemental (Born et al. 2003) and fatty acid analyses (Herman et al. 2005). A recent study capitalised on spatially explicit patterns in blubber POP concentrations to elucidate population structuring among humpback whales Megaptera novaeangliae throughout the North Pacific Ocean (Elfes et al. 2010). Geographic patterns in POP tissue concentrations have also been used to investigate fine-scale population structure in inter alia bottlenose dolphins Tursiops truncatus, narwhals Monodon monoceros and bowhead whales Balaena mysticetus (Hoekstra et al. 2002, Hansen et al. 2004, Borrell et al. 2006).

Humpback whales carry out long-distance annual migrations: over-wintering in tropical breeding grounds and foraging at high latitudes on feeding grounds. In the North Atlantic Ocean, humpback whales exhibit maternally directed site fidelity to these breeding and feeding grounds (Martin et al. 1984, Clapham \& Mayo 1987). They feed almost exclusively at higher latitudes, although feeding on breeding grounds has been rarely observed, where it is apparently limited to juveniles (Baraff et al. 1991, Gendron \& Urban 1993, De Sá Alves et al. 2009). Contaminant burdens in humpback whales are therefore primarily reflective of each individual's summer feeding ground. As such, contaminant concentrations such as those of POPs can potentially be used to infer population structure in humpback whales (Elfes et al. 2010).

The International Union for the Conservation of Nature (IUCN) recently revised the global species status of humpback whales to Least Concern from Vulnerable (Reilly et al. 2008). However, some subpopulations remain listed as Endangered (Oceania and the Arabian Sea) and the current knowledge of others is not necessarily sufficient to ascertain their specific conservation status. Humpback whales in the eastern North Atlantic are a case in point. Until recently it was thought that North Atlantic humpback whales comprised a panmictic population (Palsbøll et al. 1997), with one modern breeding ground in the West Indies (Martin et al. 1984, Smith et al. 1999). However, the Cape Verde Islands off western Africa was once an important humpback whaling ground (Reeves et al. 2002, Smith \& Reeves 2003), and recent research has revealed that some humpback whales still breed there (Jann et al. 2003, Wenzel et al. 2009). Individual humpback whales from both breeding grounds have been recorded on common feeding grounds off Iceland and in the Barents Sea (Martin et al. 1984, Jann et al. 2003, Bérubé et al. 2004, Wenzel et al. 2009), but none have been sighted on both breeding grounds. Furthermore, Cape Verdean whales have not been recorded at any of the known western North Atlantic summer feeding grounds (Jann et al. 2003, Wenzel et al. 2009).

The most recent comprehensive abundance estimate for humpback whales in the North Atlantic, from sampling carried out during 1992 and 1993, was 11570 (95\% CI $=10290$ to 13390) (Stevick et al. 2003). Of these, only 99 (coefficient of variation = 0.23 ) humpback whales are thought to breed around Cape Verde (Smith et al. 1999, Punt et al. 2006). However, 137 individual humpback whales have been sighted in Cape Verde waters since 1990 (F. Wenzel, NOAA, unpubl. data). Additional data on stock structure are needed to assess the recovery of North Atlantic humpback whales, and especially those in the eastern North Atlantic. Intrinsic markers, including POPs (Aguilar 1987), may provide insight into population connectivity and geographic range to support informed management decisions.

This paper presents results from quantitative (concentrations and ratios) and qualitative analyses (concentration-independent principal component analysis) of a suite of halogenated aromatic compounds, POPs, in the blubber lipids of humpback whales from a breeding ground (Cape Verde Islands) and a feeding or migratory stop-over area (Ireland) in the eastern North Atlantic. To our knowledge, these are the first POP concentrations to be reported for cetaceans from Cape Verde waters or indeed the tropical eastern North Atlantic. Our results are compared directly with those from a similar study in the western North Atlantic (Gulf of Maine; Elfes et al. 2010), to evaluate the hypothesis that humpback whales sampled in Cape Verde and Ireland belong to a different population than those in the Gulf of Maine. We also present 
data for the first time on sex ratios of humpback whales from Ireland and Cape Verde, to shed light on the migratory ecology of this species, which remains poorly studied in these areas.

\section{MATERIALS AND METHODS}

\section{Sample collection and preparation}

Sampling was conducted within $10 \mathrm{~km}$ of the coast at 2 eastern North Atlantic sites (Fig. 1): the southern coast of Ireland during all seasons (September 2009 to December 2012) and Boa Vista, Cape Verde, in spring (April and May 2011). Photoidentification was used to avoid duplicate sampling in the field. Humpback whales were biopsied from small boats (5 to $12 \mathrm{~m}$ ) using a crossbow (Barnett Panzer $\mathrm{V}^{\circledR}, 150 \mathrm{lb}$ [68 kg] draw-strength) with modified (CETA-DART ${ }^{\mathrm{TM}}$ ) bolts and $40 \mathrm{~mm}$ steel cutting tips (Specials Engineering) under permit from the respective governments. Sampling tips were fitted to the top of the bolts which have a compressed foam stop-collar to limit penetration, facilitate re-bound and provide buoyancy to the bolt, and to aid in retrieval without the need for a tether. Tips were scrubbed in soapy water, sterilised over a flame, rinsed in $99 \%$ ethanol and foil-wrapped prior to use. Bolts containing samples were collected from the sea after darting. Samples were removed from the tips using solvent-rinsed forceps, wrapped

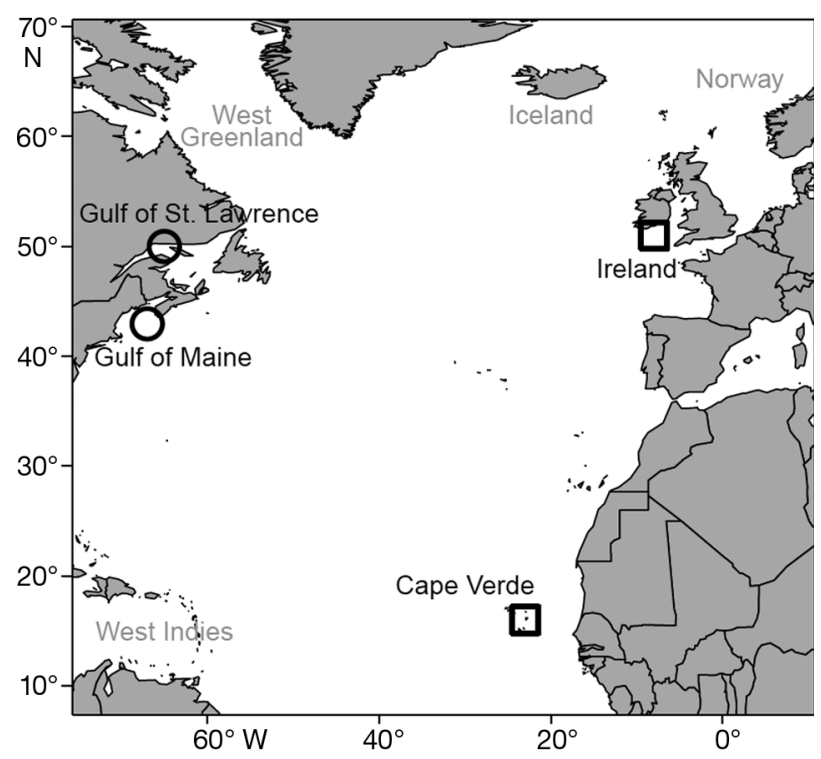

Fig. 1. Megaptera novaeangliae. Regions where samples were collected for the present study $(\square)$ and for previous studies (O), i.e. Gulf of Maine (Elfes et al. 2010) and Gulf of St. Lawrence (Gauthier et al. 1997). Other places mentioned in the text are also included in ethanol-rinsed aluminium foil and transported on ice to the laboratory (Marine Institute, Co. Galway, Ireland), whereupon they were stored in glass vials at $-80^{\circ} \mathrm{C}$. The blubber portion of each biopsy was removed from the skin and sliced thinly on a glass cutting table using a solvent-washed scalpel while still frozen to prevent lipid-loss. The skin portion was preserved in $20 \%$ salt-saturated dimethyl-sulfoxide (Amos \& Hoelzel 1991) for genetic sex determination. The entire longitudinal blubber profile available (about $30 \mathrm{~mm}$ ) was used. While the blubber depth varied between samples due to angle and distance from which the samples were obtained, none exceeded the depth of the outer blubber stratum. Biopsies were halved longitudinally, and ca. $75 \mathrm{mg}$ of blubber was used for POP analysis, and a remaining longitudinal sub-sample was retained for stable isotope analysis. The biopsy sampling methodology employed was consistent with that of a similar study in the Gulf of Maine (Elfes et al. 2010), and adult whales were targeted. While lipid composition in baleen whales may be stratified with respect to contaminant loads according to depth, mean $( \pm 1 \mathrm{SD})$, the depth of biopsy blubber profiles using $40 \mathrm{~mm}$ tips was similar between laboratories: $1.20 \mathrm{~cm}( \pm 0.26)$ (Ryan et al. 2013b) and $1.38 \mathrm{~cm}$ (SD not reported) (Elfes et al. 2010).

\section{Extraction and analysis}

Total extractable non-volatiles (hereafter referred to as lipids) were extracted using a Soxhlet apparatus with $150 \mathrm{ml}$ of research-grade, high-purity $n$-hexane and acetone in a ratio of 1:1 (Ryan et al. 2013b). Tissue samples were extracted in $100 \%$ glass microfiber thimbles (Whatman $\left.{ }^{\circledR}\right)$ for $24 \mathrm{~h}(6 \mathrm{~h}$ reflux and $18 \mathrm{~h}$ soak). Lipid weights were determined gravimetrically to the nearest milligram. Lipids were re-suspended in $n$-hexane prior to clean-up on a glass chromatography column filled with $6 \mathrm{~g}$ aluminium oxide and $0.5 \mathrm{~g}$ silica gel (both $5 \%$ [w/w] deactivated, mesh size: 0.063 to $0.200 \mathrm{~mm}$ ); $2 \mathrm{ml}$ of lipid-solvent solution were added to the column and eluted with $60 \mathrm{ml}$ of $n$-hexane. The sample was concentrated under a stream of nitrogen at $30^{\circ} \mathrm{C}$ using a TurboVap ${ }^{\circledR}$ concentrator. When reduced to approximately $5 \mathrm{ml}, 1 \mathrm{ml}$ of 2,2,4-trimethylpentane was added to the eluant to prevent complete dry-down and to largely replace $n$-hexane, as the preferred injection solvent. Samples were analysed by dual column gas chromatography with electron capture detection (GC-ECD) using a Varian 3800 with a Varian CP8400 auto-injector on 
HT8 (SGE Analytical Science) and Rtx-PCB (Restek) fused silica columns.

\section{Quality control}

Analysis was carried out in a laboratory (Marine Institute, Co. Galway, Ireland) with a track record of successful participation in QUASIMEME (Quality Assurance of Information for Marine Environmental Monitoring in Europe) proficiency exercises for the analysis of POPs. While no reference material was available for baleen whales, a full quality control programme was incorporated into the analysis batches including: procedural blanks, replicate samples, determination of contaminants in other reference marine tissues and successful participation in international proficiency studies for the analysis of POPs. Limits of quantification (LOQs) ranged from 0.013 to $0.017 \mathrm{ng} \mathrm{g}^{-1}$ (lipid based), while recovery of a spiked polychlorinated biphenyl recovery standard (PCB 112) ranged from 93 to $106 \%$, with a mean of $101 \%( \pm 0.03 \mathrm{SD})$. This was similar to the mean standard recovery of $98 \%( \pm 9 \%)$ achieved by Elfes et al. (2010), which ranged from 62 to $113 \%$. Concentrations from reference samples were within 2 standard deviations of an inter-laboratory mean for all compounds measured; therefore, analytical procedures were deemed comparable. In a similar study from the Gulf of St. Lawrence, sampling and analytical techniques (GC-ECD following Soxhletextraction in hexane) were similar to those herein, where a LOQ of 0.01 to $0.03 \mathrm{ng} \mathrm{g}^{-1}$ was achieved (Gauthier et al. 1997). However, statistical analysis between the Gulf of St. Lawrence study and ours was not possible as the types of analytes measured were not consistent (e.g. Gauthier et al. did not report PCB 28, 105, or 156).

Concentrations are reported of PCB congeners (31, $28,52,101,105,118,138,153,156$ and 180), in addition to the organochlorine pesticides (OCCs) hexachlorobenzene (HCB), the hexachlorocyclohexanes $\alpha-\mathrm{HCH}, \beta-\mathrm{HCH}$ and $\gamma-\mathrm{HCH}$ (lindane), oxychlordane, heptachlor, cis-chlordane, trans-nonachlor, dieldrin, $p, p^{\prime}$-DDE (dichlorodiphenyldichloroethylene), $o, p^{\prime}$ DDD (dichlorodiphenyldichloroethane), $p, p^{\prime}$-DDD, $o, p^{\prime}$-DDT (dichlorodiphenyltrichloroethane) and $p, p^{\prime}$ DDT. All concentrations were derived on a lipidweight basis as a sampling effect of biopsy darting leads to lipid-loss in blubber biopsies (Ryan et al. 2013b). Sums of (10) PCBs and OCC classes (chlordanes, DDTs and HCHs) were considered in order to compare pollutant profiles between sampling regions, and particularly to those reported previously by Elfes et al. (2010).

\section{Statistical analysis}

Concentrations of individual congeners from the current study were compared to those from the study by Elfes et al. (2010) on humpback whales sampled in the Gulf of Maine, allowing comparison of contaminant profiles between humpback whales from locations in the eastern and western North Atlantic. A number of statistical analyses were then completed on lipid-normalised contaminant data to partially account for potential concentration effects. Principal components analysis (PCA) was thus carried out on a concentration-independent basis. $\Sigma$ PCBs was calculated as the sum of 10 congeners; $\Sigma \mathrm{HCH}$, as the sum of $\alpha-\mathrm{HCH}, \beta-\mathrm{HCH}, \gamma-\mathrm{HCH}_{;} \Sigma$ chlordanes, as the sum of oxychlordane, heptachlor, cis-chlordane, transnonachlor; and $\Sigma \mathrm{DDT}$, as the sum of $p, p^{\prime}-\mathrm{DDE}, o, p^{\prime}-$ $\mathrm{DDD}, p, p^{\prime}$-DDD, $o, p^{\prime}$-DDT, $p, p^{\prime}$-DDT. Tests for statistical differences between concentrations of congeners between regions and sexes were carried out using multiple pair-wise Wilcoxon rank-sum tests, with a post hoc Holm-Bonferroni correction to account for Type I (false-positive) error.

PCA was used to investigate structuring within the Cape Verde sample, and between 2 potential feeding grounds (Ireland and the Gulf of Maine). A priori zero-centring and scaling were carried out to give comparable unit variance using the 'prcomp' package, and resulting ordinations were plotted using the 'vegan' package in R (R Development Core Team 2011). Scree-plots were used to assess the number of principal components that should be considered. Following a Kolmogorov-Smirnov test for normality and Levene's test for homogeneity of variance, Student's $t$-tests were employed to test if differences between principal component factor scores between regions were significant $(p<0.05)$.

\section{Sex determination}

DNA was extracted from the skin portion of each biopsy using commercial extraction kits (QIAGEN DNeasy ${ }^{\circledR}$ blood and tissue kit). Sex was determined genetically following the protocol of Bérubé \& Palsbøll (1996) using primers designed for mysticetes. A fragment of the zinc finger protein coding gene, specific to the X (ZFX) and Y (ZFY) chromosome, was amplified using 2 sets of primers. The forward primer 
anneals to both loci, whereas the reverse primers anneal to either ZFX or ZFY, yielding amplification products of different lengths. Gel electrophoresis of the PCR products through $2 \%$ agarose was used to separate the ZFX and ZFY amplification products. PCR products were stained with ethidium bromide and visualised under UV light. Positive (individuals of known sex) and negative (amplification with no genomic DNA) controls were included with each amplification as means of detecting contamination.

\section{RESULTS}

\section{Sample collection and sex determination}

A total of 40 samples of humpback whales were collected from the eastern North Atlantic: 28 from Cape Verde and 12 from Ireland (Fig. 1). Photoidentification confirmed that 2 individuals had been sampled twice (both from Cape Verde), leaving 38 individual samples for sex determination. All samples were sexed unambiguously by molecular genetic analysis as follows: Cape Verde, 9 females, 17 males; Ireland, 6 females, 6 males. A significant sex-biased distribution was found, where males were more abundant than females (1.9:1) in the samples from Cape Verde $\left(\chi^{2}=1.08,1 \mathrm{df} ; \mathrm{p}<0.05\right)$. This is a common feature of humpback whale breeding grounds (Brown et al. 1995, Palsbøll et al. 1997, Rosenbaum et al. 2009). Although based on a small sample size, the sex ratio was in parity for samples from Ireland. In total, 24 biopsy samples had sufficient tissue for POP analysis of blubber lipid: 20 (12 males, 8 females) from Cape Verde and 4 (3 males, 1 females) from Ireland.

\section{Concentrations of POP compounds}

All 10 measured PCB congeners were detected at quantifiable levels (>LOQ). Sixteen of 21 measured OCCs were also detected in all individuals (Table 1). All results are reported on a lipid basis, as extracted. However, the percentage lipid content of blubber biopsies was not presented because this is unrepresentative of the tissue in situ due to lipid-loss arising from the biopsy sampling technique (Ryan et al. 2013b).

\section{Differences in POP concentrations}

Males exhibited significantly higher burdens of several POP compounds than females (Table 1). This was particularly apparent for PCBs where the $\Sigma 10$ PCB was very highly significantly different $(p<0.005)$ between the sexes, although not every individual congener exhibited significant differences (i.e. PCBs 28, 31,153 and 180) (Table 1). Conversely, the only female in the Irish sample had higher concentrations of POPs than the mean for Irish males for all compounds measured, with the exception of PCB28, lindane and cis-chlordane. Cape Verde males had a significantly greater concentration of HCB $(p<0.01)$ than did those in Ireland; however, concentrations of all other analytes measured were not statistically different between the 2 regions (Table 1). After correction for false positives (Type I error) using the post hoc Holm-Bonferroni procedure, 6 of the 10 PCB congeners measured (PCBs 52, 101, 105, 118, 138 and 156) were present in significantly lower $(p<0.05)$ concentrations in female than in male humpbacks from Cape Verde (Table 1).

Concentrations by sums of POP classes ( $\Sigma 10$ PCBs, $\Sigma 5$ chlordanes, $\Sigma 3 \mathrm{HCH}$ and $\Sigma 5$ DDTs) were compared among regions (Fig. 2). The concentrations of summed POP classes were found to be significantly different for whales from the Gulf of Maine, whereas those from Cape Verde and Ireland were statistically indistinguishable, although based on a small sample for Irish whales (Table 1). The $\Sigma 10$ PCB level was an order of magnitude greater in whales from the Gulf of Maine compared to those from the eastern North Atlantic (Ireland and Cape Verde). The $\mathrm{SHCHs}$, however, had a higher concentration in the latter than in the former. The ratio of $\Sigma$ DDTs: $\Sigma$ PCBs (mean $\pm \mathrm{SD}$ ) was higher for males from Cape Verde $(1.69 \pm 0.41)$ and Ireland $(1.44 \pm 0.50)$, indicating proportionately greater sources of agricultural over industrial sources of pollutants than for the Gulf of Maine $(0.70 \pm 0.11)$. Our results are not comparable with those from the Gauthier et al. (1997) study, due to differences in both the lipid extraction technique used and the number of PCB congeners analysed. These data were therefore not included in our statistical analyses.

\section{Congener profiling: normalised relative to the sum of congeners}

A concentration-independent PCA for all 4 classes of POPs (normalised on the sum for each class), classified Cape Verde and Gulf of Maine humpback whales into distinct clusters (Fig. 3). A scree-plot for the PCA of all compounds (normalised on the sum of each class, see 'Materials and methods') indicated that the first 3 principal components (PC) were cumu- 
Table 1. Megaptera novaeangliae. Mean \pm standard deviation (range) concentrations (ng $\mathrm{g}^{-1}$ lipid weight) of persistent organic pollutant analytes measured in the present study (Cape Verde and Ireland) and those measured by Elfes et al. (2010) (Gulf of Maine). For Cape Verde, Holm-Bonferroni-corrected Mann-Whitney U-test was used between sexes. For Cape Verde and Ireland, Holm-Bonferroni-corrected Mann-Whitney $U$-test was used between males. PCB: polychlorinated biphenyls; HCH: hexachlorocyclohexanes; DDD: dichlorodiphenyldichloroethane; DDT: dichlorodiphenyltrichloroethane; DDE: dichlorodiphenyldichloroethylene; HCB: hexachlorobenzene ${ }_{i}^{*}: \mathrm{p}<0.05_{i}^{* *}: \mathrm{p}<0.01{ }^{* * *}: \mathrm{p}<0.005$; NA: not applicable

\begin{tabular}{|c|c|c|c|c|c|}
\hline \multirow{2}{*}{ Congener } & \multicolumn{2}{|c|}{ Cape Verde } & \multicolumn{2}{|c|}{${ }_{-}$Ireland $\longleftarrow$} & \multirow{2}{*}{$\begin{array}{l}\text { Gulf of Maine } \\
\text { Male }(\mathrm{n}=20)\end{array}$} \\
\hline & Female $(\mathrm{n}=8)$ & Male $(\mathrm{n}=12)$ & Female (n = 1) & Male $(\mathrm{n}=3)$ & \\
\hline PCB31 & $2 \pm 1(1-4)$ & $9 \pm 13(1-44)$ & 6 & $2 \pm 2(1-5)$ & $1 \pm 0(1-6)$ \\
\hline PCB28 & $4 \pm 1(3-5)$ & $6 \pm 3(1-14)$ & 3 & $5 \pm 4(2-10)$ & $2 \pm 1(1-7)$ \\
\hline PCB52 & $13 \pm 13(0-34)^{* *}$ & $40 \pm 25(10-86)$ & 54 & $16 \pm 8(7-22)$ & $85 \pm 33(34-140)$ \\
\hline PCB101 & $6 \pm 8(1-20)^{* *}$ & $22 \pm 14(6-50)$ & 23 & $13 \pm 11(1-21)$ & $84 \pm 37(28-170)$ \\
\hline PCB118 & $21 \pm 20(6-57)^{* * *}$ & $55 \pm 37(16-127)$ & 45 & $20 \pm 15(3-33)$ & $197 \pm 88(79-410)$ \\
\hline PCB153 & $35 \pm 31(9-89)$ & $77 \pm 54(16-182)$ & 100 & $63 \pm 53(9-115)$ & $570 \pm 489(210-2400)$ \\
\hline PCB105 & $2 \pm 1(1-4)^{* * *}$ & $8 \pm 4(2-16)$ & 9 & $4 \pm 1(3-5)$ & $28 \pm 11(11-52)$ \\
\hline PCB138 & $28 \pm 21(9-65)^{*}$ & $63 \pm 43(17-144)$ & 75 & $36 \pm 26(8-60)$ & $432 \pm 342(160-1700)$ \\
\hline PCB156 & $2 \pm 1(1-4)^{*}$ & $5 \pm 4(1-12)$ & 4 & $3 \pm 2(1-6)$ & $17 \pm 8(6-38)$ \\
\hline PCB180 & $6 \pm 4(1-12)$ & $14 \pm 11(2-32)$ & 18 & $12 \pm 11(1-23)$ & $129 \pm 134(33-630)$ \\
\hline$\alpha-\mathrm{HCH}$ & $6 \pm 2(3-9)$ & $6 \pm 3(1-13)$ & 3 & $2 \pm 1(1-2)$ & $6 \pm 3(2-10)$ \\
\hline$\beta-\mathrm{HCH}$ & $1 \pm 0(0-2)$ & $2 \pm 1(0-4)$ & NA & $7 \pm 11(0-20)$ & $6 \pm 5(1-16)$ \\
\hline$\gamma$-HCH (lindane) & $11 \pm 3(8-18)$ & $14 \pm 13(4-51)$ & 4 & $5 \pm 2(3-7)$ & $2 \pm 1(1-3)$ \\
\hline cis-Chlordane & $10 \pm 7(4-22)$ & $11 \pm 9(2-37)$ & 2 & $4 \pm 4(0-8)$ & $9 \pm 4(3-16)$ \\
\hline Heptachlor & $20 \pm 21(2-57)$ & $35 \pm 29(4-107)$ & 21 & $13 \pm 11(1-22)$ & $1 \pm 1(1-3)$ \\
\hline Oxychlordane & $20 \pm 21(4-56)^{*}$ & $40 \pm 24(11-92)$ & 35 & $20 \pm 13(5-29)$ & $53 \pm 34(13-150)$ \\
\hline trans-Nonachlor & $74 \pm 71(16-196)$ & $142 \pm 96(33-356)$ & 134 & $82 \pm 67(7-132)$ & $274 \pm 178(99-830)$ \\
\hline$o, p^{\prime}-\mathrm{DDD}$ & $16 \pm 17(4-46)$ & $22 \pm 17(0-54)$ & 29 & $8 \pm 4(4-11)$ & $18 \pm 10(5-51)$ \\
\hline$o, p^{\prime}-\mathrm{DDT}$ & $29 \pm 34(3-98)$ & $69 \pm 62(8-210)$ & 77 & $22 \pm 9(14-31)$ & $62 \pm 113(13-530)$ \\
\hline$p, p^{\prime}-\mathrm{DDD}$ & $46 \pm 52(8-138)^{*}$ & $85 \pm 54(21-202)$ & 93 & $38 \pm 33(1-66)$ & $249 \pm 201(77-900)$ \\
\hline$p, p^{\prime}-\mathrm{DDE}$ & $143 \pm 152(28-405)$ & $302 \pm 228(54-789)$ & 305 & $164 \pm 142(4-275)$ & $799 \pm 702(240-3200)$ \\
\hline$p, p^{\prime}-\mathrm{DDT}$ & $21 \pm 22(2-60)$ & $27 \pm 25(4-94)$ & 42 & $19 \pm 19(1-39)$ & $46 \pm 29(16-140)$ \\
\hline $\mathrm{HCB}$ & $74 \pm 55(28-166)^{*}$ & $137 \pm 81(68-343)$ & 71 & $19 \pm 5(16-25)^{* *}$ & $47 \pm 20(18-99)$ \\
\hline Dieldrin & $1 \pm 1(0-3)$ & $41 \pm 89(0-279)$ & 201 & $59 \pm 95(1-169)$ & $180 \pm 88(63-400)$ \\
\hline$\Sigma \mathrm{PCBs}$ & $120 \pm 96(46-285)^{* * *}$ & $299 \pm 198(86-690)$ & 337 & $174 \pm 128(40-295)$ & $1545 \pm 1072(563-5393)$ \\
\hline ¿Chlordanes & $129 \pm 122(28-342)^{*}$ & $236 \pm 153(60-622)$ & 192 & $123 \pm 96(14-192)$ & $337 \pm 211(117-984)$ \\
\hline$\Sigma \mathrm{HCHs}$ & $18 \pm 3(13-23)$ & $22 \pm 16(8-67)$ & NA & $14 \pm 14(5-30)$ & $14 \pm 7(4-28)$ \\
\hline$\Sigma \mathrm{DDTs}$ & $256 \pm 276(48-747)$ & $505 \pm 375(95-1350)$ & 547 & $251 \pm 202(24-411)$ & $1149 \pm 1014(347-4681)$ \\
\hline
\end{tabular}

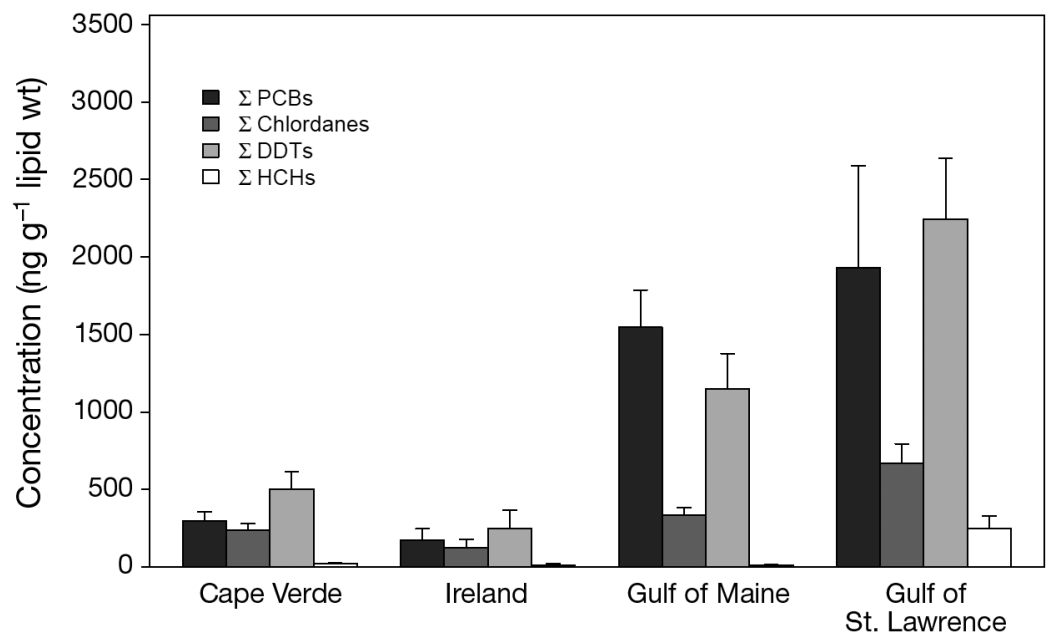

Fig. 2. Megaptera novaeangliae. Mean $( \pm \mathrm{SD})$ concentrations of persistent organic pollutant classes (sums of congeners), presented in ng per g lipid weight. Data for the eastern North Atlantic (Cape Verde and Ireland) are from the present study. Data for the Gulf of Maine are from Elfes et al. (2010); data from the Gulf of St. Lawrence are from Gauthier et al. (1997). Note that the extraction methods and number of PCB congeners from the latter are not consistent with the present study. For abbreviations see Table 1 latively responsible for $66.8 \%$ of the variance. Females had been excluded from the Gulf of Maine study (Elfes et al. 2010), and were also excluded here for the purpose of comparison between the 2 studies, given the sex bias observed in POP profiles. Eastern North Atlantic (Cape Verde and Ireland combined) and Gulf of Maine clusters were significantly different with respect to the first factor $(t=$ $-8.47, \mathrm{df}=18, \mathrm{p}<0.01$ ), but not with the second factor $(t=-1.42, \mathrm{df}=16, \mathrm{p}=$ 0.17 ). The loadings (both PC1 and PC2) indicated that PCBs 138, 153 and 180 were highly influential eigenvalues for Gulf of Maine whales, whereas eigenvalues for eastern North Atlantic samples were characterised by less recalcitrant PCBs $(28,31,52,105,118$ and 156). Loadings from trans-nona- 


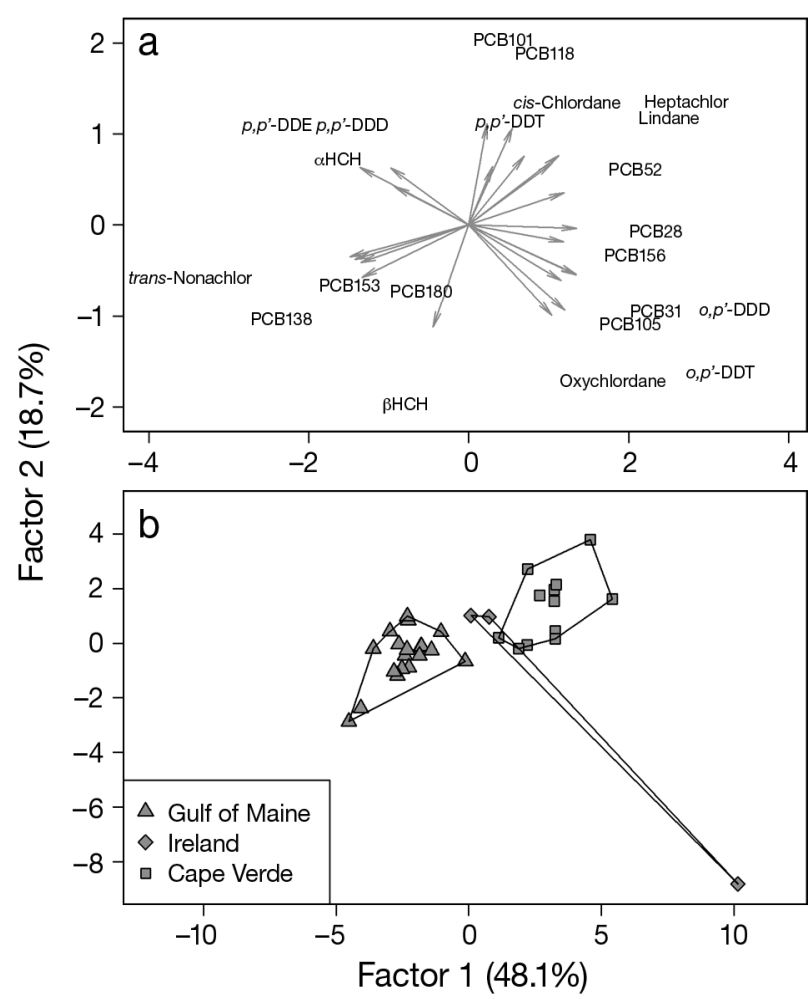

Fig. 3. Megaptera novaeangliae. Principal components analysis (PCA) of concentration-independent persistent organic pollutants (normalised by $\Sigma 10 \mathrm{PCB}, \Sigma 3 \mathrm{HCH}, \Sigma 5 \mathrm{DDT}$ and $\Sigma 5$ chlordanes) in blubber lipid of male humpback whales. (a) PCA loadings according to analyte. (b) PCA scores where lines are convex hulls according to sampling region (Gulf of Maine data from Elfes et al. 2010). Percentages denote the proportion of variance described by the respective principal components. For abbreviations see Table 1

chlor strongly influenced the biplot distribution of Gulf of Maine whales, whereas the remaining chlordanes (heptachlor, cis-chlordane and oxychlordane) were more influential to analytical results for loadings from Cape Verde and Ireland (Fig. 3).

\section{DISCUSSION}

\section{Levels of persistent organochlorine pollutants}

Overall, concentrations of POP compounds in humpback whale blubber lipid were generally an order of magnitude lower in the whales from Cape Verde and Ireland compared to both the Gulf of Maine (Elfes et al. 2010) and those sampled from the Gulf of St. Lawrence (Gauthier et al. 1997) in the western North Atlantic. Notable exceptions were observed for HCB, HCHs, PCB31 and PCB28. With the exception of $\mathrm{HCHs}$, levels of all classes of POPs in whales from the eastern North Atlantic reported here were higher than those from the Pacific (Alaska, Aleutian Islands, Bering Sea and California) (Elfes et al. 2010). While Elfes et al. (2010) utilised methylene chloride extraction, as against $n$-hexane/acetone, followed by sizeexclusion high-performance liquid chromatography (SEC-HPLC) with subsequent gas chromatography/ mass spectrometry (GC/MS) detection, we argue that the analytical specificity and limits of quantification are comparable between studies (see 'Materials and methods' section for LOQ). HCH concentrations in humpback whales sampled in the Gulf of St. Lawrence were an order of magnitude higher than those presented herein, which may be due to the high levels of pesticide application on Canadian farms adjacent to the region (Tuduri et al. 2006). HCH levels in Pacific humpback whales are generally higher than those in the western North Atlantic (Elfes et al. 2010).

All lipid-normalised PCB concentrations presented here were below the estimated threshold toxicity value of $17000 \mathrm{ng} \mathrm{g}^{-1}$ for blubber in marine mammals (Kannan et al. 2000). Some PCB congeners such as 105, 118 and 156 have dioxin-like properties and have thus been assigned toxic equivalency factors by the World Health Organisation to facilitate risk assessment (Van den Berg et al. 2006). Whales from the eastern North Atlantic exhibited a pattern consistent with lower metabolic response to these dioxinlike contaminants than did whales from the Gulf of Maine, a highly industrialised region of North America. POP profiles of Gulf of Maine whales were characterised by more recalcitrant PCBs, whereas those in the eastern North Atlantic had higher proportions of lower condensed (i.e. relatively more volatile) PCB congeners (Fig. 3). This suggests that the source of observed PCB residue concentrations in whales from the eastern North Atlantic is better explained by atmospheric transport by diffusion, rather than pointsource contamination. This is consistent with likely higher latitude feeding grounds for humpbacks sampled in Cape Verde. Indeed, all of the photographic recaptures of humpback whales between Cape Verde and their feeding grounds to date have occurred at high latitudes above $65^{\circ} \mathrm{N}$ (Jann et al. 2003, Wenzel et al. 2009).

Despite the extensive use of DDT in the tropics, chiefly for malaria control, there are few studies which report on concentrations in mammals there (Schenker et al. 2008). DDT has been used intensively in West Africa to successfully combat malaria, e.g. the World Health Organisation promoted the use of indoor residual spraying in 2006 (Sadasivaiah et al. 2007). While it is possible that whales near Cape 
Verde inhale gas or particulate DDT while on their West African breeding ground, the predominant source of DDT is likely dietary (Aguilar et al. 1999). Widespread bans on the use of DDT in some parts of the world have led to a global decline in the environment, with a simultaneous relative increase in the metabolised forms such as $p, p^{\prime}$-DDD and $p, p^{\prime}$-DDE. Therefore, DDT ratios in animal tissues can shed light on biogeographic patterns inferred by regional differential persistence or metabolisation. The percent $( \pm \mathrm{SD}) p, p^{\prime}-\mathrm{DDE}: \Sigma \mathrm{DDT}$ was found to be $51.8 \%$ $( \pm 0.23)$ for Irish and $57.7 \%( \pm 0.04)$ for Cape Verde whales. This compares with $68.9 \%( \pm 0.04)$ for Gulf of Maine and $70.9 \%( \pm 0.15)$ for humpback whales in the Gulf of St. Lawrence (calculated from Gauthier et al. 1997). Samples from Cape Verde and Ireland therefore show relatively higher proportions of technical DDT and lower levels of metabolised forms of DDT than those whales sampled in the Gulf of Maine or the Gulf of St. Lawrence.

The sex-biased distribution of POP concentrations observed herein is consistent with most mammalian studies and may be explained by the potential for reproductive transfer exhibited by females, whereby lipophilic contaminants are transferred to offspring directly across placental membranes during gestation, and thereafter by lactation (Aguilar \& Borrell 1994). Due consideration must be given to many other possible sources of variation in xenobiotic residues in tissues. Variation may arise from differences in diet or trophic level (Muir et al. 1988), geographic range (Elfes et al. 2010), nutritive condition (Aguilar et al. 1999), metabolic rate (Tanabe et al. 1988), birth-order (Ylitalo et al. 2001), or body mass and age (Aguilar \& Borrell 1988). In this study, concentrations were normalised on the sum of PCBs to reduce the effects of some of these cofactors. There are, however, interactions between several other potentially confounding factors (e.g. body size and metabolic rate). Measures to address these potential effects were taken in this study by only sampling adult whales. There is also evidence of potentially confounding mechanisms affecting tissue concentrations. Mysticetes undergo prolonged fasting with changes in both blubber lipid content and composition, whereby body mass may be reduced by one-third to one-half (Dawbin \& Norris 1966, Lockyer 1987, Aguilar \& Borrell 1990). Such changes may lead to a concentration of lipophilic xenobiotics such as POPs when lipid stores are metabolised, culminating in increased tissue concentrations while fasting during the breeding season. However, the influence of nutritive condition on organochlorine concentrations in humpback whales is unknown. Blubber biopsies taken from identified individuals on both their feeding and breeding grounds could be used to address this shortfall in our knowledge.

\section{Sex ratio}

As discussed above, an important consideration when comparing concentrations of POPs between samples from regions is the sex of the individuals, as females will transfer burdens to their offspring, whereas males will not. Determining sex for each biopsy sample presented the opportunity to investigate the sex ratio of humpback whales from both Ireland and Cape Verde for the first time. The sex ratio can provide important information on the ecology of humpback whales in these areas which remain poorly studied. Although based on a small sample $(\mathrm{n}=26)$, the male bias at 1.9 among the Cape Verde samples was similar to those estimated on other breeding grounds (Palsbøll et al. 1997, Rosenbaum et al. 2009). It has been suggested that a male sex bias among breeding ground samples is due to pregnant females overwintering on the summer feeding grounds (Brown et al. 1995). However, Palsbøll et al. (1997) concluded that this did not explain the sex bias found in their study of the West Indies breeding population. Instead, a longer winter residency by males or higher site fidelity by females (or a combination of the two) is likely to account for the male sex bias on breeding grounds (Palsbøll et al. 1997). The sex ratio of humpback whales did not deviate significantly from parity in Ireland, nor at any of the North Atlantic feeding locations that have been investigated to date. This result is consistent with Ireland representing a feeding ground or migratory stopover point (Charif et al. 2001)

\section{Factors influencing observed POP concentrations}

Differential transportability and regional inputs have contributed to latitudinal patterns of various classes of POPs (Iwata et al. 1993). In particular, both HCHs and HCB exhibit a strong positive latitudinal cline (Simonich \& Hites 1995). Cape Verde male humpback whales exhibited significantly higher proportions of HCB and HCH levels compared to Gulf of Maine males, despite lower levels of all other POP congeners. Therefore, our results suggest that Cape Verde whales forage at higher latitudes than the Gulf of Maine. HCB and $\mathrm{HCHs}$, which are associated with 
intensive agriculture, have been recorded in aerosols at high latitude humpback whale feeding grounds in the eastern North Atlantic (Jan Mayen and Bear Island), at concentrations higher than in the surrounding Atlantic, and comparable to those of densely populated areas of the USA (Pacyna \& Oehme 1988). High proportions of $\mathrm{HCB}, \mathrm{HCHs}$ and the high $\mathrm{LDDT}$ : $\Sigma \mathrm{PCB}$ ratio in Cape Verdean and Irish humpback whales are all consistent with pollutant burdens deriving from agricultural rather than industrial sources. Geographic patterns of $\mathrm{HCB}$ and $\mathrm{HCH}$ compounds in the tissues of predators, when not confounded by trophic enrichment, can be useful in detecting spatially explicit populations and hence stock structure (Hoekstra et al. 2002, Borrell et al. 2006, Dickhut et al. 2009). While this was not possible in the current study due to the geographically restricted sample, the differences in POP profiles between eastern North Atlantic and Gulf of Maine samples suggests that this tool has the potential to delineate stock structure in North Atlantic humpback whales.

\section{Towards investigating population structure in North Atlantic humpback whales using POPs}

In isolation, POP concentrations may be ineffective in discriminating between populations due to their high variability and numerous confounding factors (e.g. sex, age and diet). In cetaceans, the POP burden arises chiefly via diet, i.e. from prey (Aguilar et al. 1999). Diet and trophic level may vary among individual whales, and POP sources may vary due to temporal variance in prey composition at a specific feeding locality. However, both sampling location and regional prey availability may give rise to marked spatial patterns of contaminant levels in humpback whales (Elfes et al. 2010). By extension, inferences can be made regarding the broader distribution of humpback whales in the North Atlantic, assuming that humpback whales from all study areas have obtained their POP burdens primarily from the same kinds of prey.

Our results provide no evidence of connectivity between humpback whales from Cape Verde or Ireland with those summering in the Gulf of Maine (or indeed the Gulf of St. Lawrence). Further POP analysis using the methodological framework presented here (Fig. 3) may allow assignment of Cape Verdean whales to specific feeding grounds. However, such an analysis should include samples from the other known breeding ground (the West Indies) and major feeding grounds (Newfoundland/Labrador, Iceland,
Norway and West Greenland) in the North Atlantic. This would complement on-going molecular genetic studies into reproductive isolation between the 2 known North Atlantic breeding grounds. Spatial structuring of humpback whale populations in the North Atlantic remains at least partly unresolved (Palsbøll et al. 2001, Pike et al. 2009), and should be a research priority towards more informed conservation goals. This is particularly urgent in light of the apparently small breeding population of humpback whales in Cape Verde, which if the current abundance estimates of between 99 and 137 individuals are accurate, is vulnerable to anthropogenic and stochastic threats to its survival similar to those of North Atlantic right whales Eubalaena glacialis (Caswell et al. 1999, Fujiwara \& Caswell 2001).

\section{Conclusions}

PCB and DDT concentrations in humpback whales sampled in the eastern North Atlantic were lower than threshold toxicity levels for blubber in marine mammals and almost an order of magnitude lower than those in Gulf of Maine whales (males only). Compared to those sampled in the Gulf of Maine, males from the eastern North Atlantic exhibited higher concentrations of lower condensed (i.e. more volatile) PCB congeners (28, 31 and 52), as well as HCHs and $\mathrm{HCB}$, both of which are usually associated with high latitudes. The contaminant profiles of humpback whales from Irish waters were similar to those from Cape Verde for most POP compounds considered. The present study suggests that POP profiling may be useful in clarifying unresolved aspects of population structure in humpback whales in the North Atlantic. In light of their small estimated population size and the possibility of reproductive isolation, we urge further research to facilitate a more thorough assessment of the conservation status of the putative eastern North Atlantic humpback whale population. The relatively low POP concentrations in the blubber lipids of Cape Verde humpback whales suggest that POPs are unlikely to be a factor in the poor recovery rate of this small putative population.

Acknowledgements. C.R. acknowledges that funding was provided by the Irish Research Council for Science, Engineering and Technology. C.R. and S.D.B. are particularly grateful to the Island Foundation for funding fieldwork in Cape Verde and to the Heritage Council, National Parks and Wildlife Service and Irish Environmental Network for sponsoring the fieldwork in Ireland. C.R. acknowledges a Marine Institute Networking Travel Grant to visit the University of 
Groningen and an Ireland-Newfoundland Partnership grant. We are indebted to F. Wenzel, B. Jann and the INDP (Institute for the Development of Fisheries in Cape Verde) for their assistance. Biopsy samples were collected under license from the National Parks and Wildlife Service, Ireland (License Numbers C76/2008, C82/2009 \& C130/2010) and Direcção Geral do Ambiente, Cape Verde (Licence Number 03/2011). Humpback whale tissues were imported to Ireland under CITES permit (ECR113/11).

\section{LITERATURE CITED}

Aguilar A (1987) Using organochlorine pollutants to discriminate marine mammal populations: a review and critique of the methods. Mar Mamm Sci 3:242-262

Aguilar A, Borrell A (1988) Age- and sex-related changes in organochlorine compound levels in fin whales (Balaenoptera physalus) from the eastern North Atlantic. Mar Environ Res 25:195-211

Aguilar A, Borrell A (1990) Patterns of lipid content and stratification in the blubber of fin whales (Balaenoptera physalus). J Mammal 71:544-554

Aguilar A, Borrell A (1994) Reproductive transfer and variation of body load of organochlorine pollutants with age in fin whales (Balaenoptera physalus). Arch Environ Contam Toxicol 27:546-554

Aguilar A, Borrell A, Pastor T (1999) Biological factors affecting variability of persistent pollutant levels in cetaceans. J Cetacean Res Manag 1(Spec Issue):83-116

Aguilar A, Borrell A, Reijnders PJH (2002) Geographical and temporal variation in levels of organochlorine contaminants in marine mammals. Mar Environ Res 53:425-452

Amos W, Hoelzel AR (1991) Long-term preservation of cetacean tissue at ambient temperature for molecular genetic analysis. In: Hoelzel AR (ed) Genetic ecology of whales and dolphins. International Whaling Commission, Cambridge, p 99-104

Baraff LS, Clapham PJ, Mattila DK, Bowman RS (1991) Feeding behavior of a humpback whale in low-latitude waters. Mar Mamm Sci 7:197-202

Bérubé M, Palsbøll P (1996) Identification of sex in cetaceans by multiplexing with three ZFX and ZFY specific primers. Mol Ecol 5:283-287

Bérubé M, Rew MB, Cole T, Swartz SL and others (2004) Genetic identification of an individual humpback whale between the eastern Caribbean and the Norwegian Sea. Mar Mamm Sci 20:657-663

Born EW, Outridge P, Riget FF, Hobson KA and others (2003) Population substructure of North Atlantic minke whales (Balaenoptera acutorostrata) inferred from regional variation of elemental and stable isotope signatures in tissues. J Mar Syst 43:1-17

Borrell A, Aguilar A, Tornero V, Sequeira M and others (2006) Organochlorine compounds and stable isotopes indicate bottlenose dolphin subpopulation structure around the Iberian Peninsula. Environ Int 32:516-523

Brown MR, Corkeron PJ, Hale PT, Schultz KW, Bryden MM (1995) Evidence for a sex-segregated migration in the humpback whale (Megaptera novaeangliae). Proc R Soc Lond B Biol Sci 259:229-234

Caswell H, Fujiwara M, Brault S (1999) Declining survival probability threatens the North Atlantic right whale. Proc Natl Acad Sci USA 96:3308-3313

Charif RA, Clapham PJ, Clark CW (2001) Acoustic detec- tions of singing humpback whales in deep waters off the British Isles. Mar Mamm Sci 17:751-768

Clapham PJ, Mayo CA (1987) Reproduction and recruitment of individually identified humpback whales, Megaptera novaeangliae, observed in Massachusetts Bay, 19791985. Can J Zool 65:2853-2863

Dawbin WH, Norris KS (1966) The seasonal migratory cycle of humpback whales. In: Norris KS (ed) Whales, dolphins and porpoises. University of California Press, Berkley, CA, p 145-171

$>$ De Sá Alves LC, Andriolo A, Zerbini AN, Pizzorno JL, Clapham PJ (2009) Record of feeding by humpback whales (Megaptera novaeangliae) in tropical waters off Brazil. Mar Mamm Sci 25:416-419

> Dickhut RM, Deshpande AD, Cincinelli A, Cochran MA and others (2009) Atlantic bluefin tuna (Thunnus thynnus) population dynamics delineated by organochlorine tracers. Environ Sci Technol 43:8522-8527

Donovan GP (1991) A review of IWC stock boundaries. Rep Int Whal Comm 13(Spec issue):39-68

Elfes CT, VanBlaricom GR, Boyd D, Calambokidis J and others (2010) Geographic variation of persistent organic pollutant levels in humpback whale (Megaptera novaeangliae) feeding areas of the North Pacific and North Atlantic. Environ Toxicol Chem 29:824-834

Fujiwara M, Caswell H (2001) Demography of the endangered North Atlantic right whale. Nature 414:537-541

Gauthier J, Metcalfe C, Sears R (1997) Chlorinated organic contaminants in blubber biopsies from northwestern Atlantic balaenopterid whales summering in the Gulf of St. Lawrence. Mar Environ Res 44:201-223

- Gendron D, Urban RJ (1993) Evidence of feeding by humpback whales (Megaptera novaeangliae) in the Baja California breeding ground, Mexico. Mar Mamm Sci 9:76-81

> Hansen LJ, Schwacke LH, Mitchum GB, Hohn AA and others (2004) Geographic variation in polychorinated biphenyl and organochlorine pesticide concentrations in the blubber of bottlenose dolphins from the US Atlantic coast. Sci Total Environ 319:147-172

Herman DP, Burrows DG, Wade PR, Durban JW and others (2005) Feeding ecology of eastern North Pacific killer whales Orcinus orca from fatty acid, stable isotope, and organochlorine analyses of blubber biopsies. Mar Ecol Prog Ser 302:275-291

> Hoekstra PF, O'Hara TM, Pallant SJ, Solomon KR, Muir DCG (2002) Bioaccumulation of organochlorine contaminants in bowhead whales (Balaena mysticetus) from Barrow, Alaska. Arch Environ Contam Toxicol 42: 497-507

Iwata H, Tanabe S, Sakai N, Tatsukawa R (1993) Distribution of persistent organochlorines in the oceanic air and surface seawater and the role of ocean in their global transport and fate. Environ Sci Technol 27:1080-1098

Jann B, Allen J, Carrillo M, Hanquet S and others (2003) Migration of a humpback whale between the Cape Verde Islands and Iceland. J Cetacean Res Manag 5: 125-129

Kannan K, Blankenship AL, Jones PD, Giesy JP (2000) Toxicity reference values for the toxic effects of polychlorinated biphenyls to aquatic mammals. Hum Ecol Risk Assess 6:181-201

Krahn MM, Herman DP, Matkin CO, Durban JW and others (2007) Use of chemical tracers in assessing the diet and foraging regions of eastern North Pacific killer whales. Mar Environ Res 63:91-114 
Lockyer C (1987) Evaluation of the role of fat reserves in relation to the ecology of North Atlantic fin and sei whales. In: Huntley AC, Costa DP, Worthy GAJ, Castellini MA (eds) Approaches to marine mammal energetics. Society of Marine Mammalogy, University of California, CA, p 183-203

Martin AR, Katona SK, Matilla D, Hembree D, Waters TD (1984) Migration of humpback whales between the Caribbean and Iceland. J Mammal 65:330-333

> Muir DC, Norstrom RJ, Simon M (1988) Organochlorine contaminants in arctic marine food chains: accumulation of specific polychlorinated biphenyls and chlordanerelated compounds. Environ Sci Technol 22:1071-1079

Pacyna JM, Oehme M (1988) Long-range transport of some organic compounds to the Norwegian Arctic. Atmos Environ 22:243-257

Palsbøll PJ, Allen J, Berube M, Clapham PJ and others (1997) Genetic tagging of humpback whales. Nature 388: 767-769

Palsbøll JP, Allen J, Andersen TH, Bérubé M and others (2001) Stock structure and composition of the North Atlantic humpback whale, Megaptera novaeangliae. Rep Int Whal Comm SC/53/NAH11, p 29

Pike DG, Víkingsson GA, Gunnlaugsson T, Øien N (2009) A note on the distribution and abundance of blue whales (Balaenoptera musculus) in the Central and Northeast North Atlantic. NAMMCO Sci Publ 7:19-29

Punt AE, Friday NA, Smith TD (2006) Reconciling data on the trends and abundance of North Atlantic humpback whales within a population modelling framework. J Cetacean Res Manag 8:145-159

R Development Core Team (2011) R: a language and environment for statistical computing. R Foundation for Statistical Computing, Vienna

Reeves R, Clapham PJ, Wetmore SE (2002) Humpback whale (Megaptera novaeangliae) occurrence near the Cape Verde Islands, based on American 19th century whaling records. J Cetacean Res Manag 4:235-254

Reilly SB, Bannister JL, Best PB, Brown M and others (2008) Megaptera novaeaengliae. In: IUCN Red List of Threatened Species, Version 2013.1. Available at: www.iucn redlist.org (accessed 15 September 2013)

Rosenbaum HC, Pomilla C, Mendez M, Leslie MS and others (2009) Population structure of humpback whales from their breeding grounds in the South Atlantic and Indian Oceans. PLoS ONE 4:e7318

Ryan C, McHugh B, Trueman CN, Sabin R and others (2013a) Stable isotope analysis of baleen reveals resource

Editorial responsibility: Brendan Godley, University of Exeter, Cornwall Campus, UK partitioning among sympatric rorquals and population structure in fin whales. Mar Ecol Prog Ser 479:251-261

Ryan C, McHugh B, O'Connor I, Berrow SD (2013b) Lipid content in blubber biopsies is not representative of blubber in situ for fin whales (Balaenoptera physalus). Mar Mamm Sci 29:542-547

Sadasivaiah S, Tozan Y, Breman JG (2007) Dichlorodiphenyltrichloroethane (DDT) for indoor residual spraying in Africa: How can it be used for malaria control? Am J Trop Med Hyg 77:249-263

Schenker U, Scheringer M, Hungerbühler K (2008) Investigating the global fate of DDT: model evaluation and estimation of future trends. Environ Sci Technol 42:1178-1184

Simonich SL, Hites RA (1995) Organic pollutant accumulation in vegetation. Environ Sci Technol 29:2905-2914

Smith TD, Reeves RR (2003) Estimating American 19th century catches of humpback whales in the West Indies and Cape Verde Islands. Caribb J Sci 39:286-297

Smith TD, Allen J, Clapham PJ, Hammond PS and others (1999) An ocean-basin-wide mark-recapture study of the North Atlantic humpback whale (Megaptera novaeangliae). Mar Mamm Sci 15:1-32

> Stevick PT, Allen J, Clapham PJ, Friday N and others (2003) North Atlantic humpback whale abundance and rate of increase four decades after protection from whaling. Mar Ecol Prog Ser 258:263-273

> Tanabe S, Watanabe S, Kan H, Tatsukawa R (1988) Capacity and mode of PCB metabolism in small cetaceans. Mar Mamm Sci 4:103-124

> Tuduri L, Harner T, Blanchard P, Li YF and others (2006) A review of currently used pesticides (CUPs) in Canadian air and precipitation: Part 1: Lindane and endosulfans. Atmos Environ 40:1563-1578

Van den Berg M, Birnbaum LS, Denison M, De Vito M and others (2006) The 2005 World Health Organization reevaluation of human and mammalian toxic equivalency factors for dioxins and dioxin-like compounds. Toxicol Sci 93:223-241

Wenzel FW, Allen J, Berrow S, Hazevoet CJ and others (2009) Current knowledge on the distribution and relative abundance of humpback whales (Megaptera novaeangliae) off the Cape Verde Islands, eastern North Atlantic. Aquat Mamm 35:502-510

Ylitalo GM, Matkin CO, Buzitis J, Krahn MM and others (2001) Influence of life-history parameters on organochlorine concentrations in free-ranging killer whales (Orcinus orca) from Prince William Sound, AK. Sci Total Environ 281:183-203

Submitted: September 19, 2012; Accepted: September 16, 2013 Proofs received from author(s): November 24, 2013 